and Immigration Services. If they can't find one, they must leave the country or change their immigration status. Lal says that his wife had to give up her $\mathrm{H}-1 \mathrm{~B}$ for an $\mathrm{H}-4$ dependent visa - conditionally available to immediate family members of someone on an $\mathrm{H}-1 \mathrm{~B}$ visa - after losing her research position. H-4-visa holders generally aren't allowed to work, so Lal has to support the family himself.

\section{APPLICATION LABRYINTH}

Foreign researchers who want to work in the United States should be upfront about immigration issues when interviewing for positions, Lal says. "Many PIs have no idea about visa requirements," he says. "I was very clear with potential employers. I told them that I needed them to sponsor my visa. Having that nailed down before you join a lab protects you from exploitation." He says that he also checked with other international lab members to see if they'd had any trouble. "It takes courage to bring up this topic during an interview," he says. "But you have to be clear about your goals. Visa issues can give people nightmares," he adds (see 'Tactics for an airtight visa case').

Scientists can gain a more secure footing by applying for a 'green card', a type of visa that confers permanent-residency status. Green cards have already been a source of contention in the White House. Days after Trump issued a 90-day travel restric-

tion on entry into the United States for nationals of seven countries, his chief of staff announced that green-card holders from those "No country
has enough
talent to do
quality science.
Youneed
immigrants." countries would be admitted on a case-by-case basis. The ban was halted in mid-February, but a new executive order was expected to be released the following week.

Anyone seeking a green card should start the process a couple of years in advance, says Neilia Gracias, a neuroscientist at the University of California, Davis, who received her green card in 2014. Gracias, who is from India, says that her application was nearly 1,000 pages long, a testament to the complexity of the endeavour. The application included a 25-page personal statement that took her a month to write. She also had ten letters of recommendation - and importantly, sought out scientists who were familiar with her work but didn't know her personally. "They are assessing skills," she says. "It doesn't matter if you're a diligent worker or can get along with people."

Scientists who want a green card must demonstrate a track record of publishing papers and winning grants. But with citizenship on the line, the pressure to succeed is especially intense, Gracias says. "You need to start building credentials," she says. "If you aren't getting publications, you might have to change labs."
As do many in her position, Gracias decided to hire a lawyer to help with the process. "There was no way I was going to do it on my own," she says. Lawyers can charge as much as US\$5,000 for the service, but Gracias got a discount from a qualified friend. Among other things, the lawyer helped her to make the case that she had valuable skills to offer her new country. The lawyer also included a picture of a neuron on the application, an eyecatching touch to underscore the importance of her research. Gracias waited a year for her green card to be approved - longer than some people she knows, but shorter than others. "I don't think it should be so hard for highly educated people to get a green card," she says. "No country has enough talent to do quality science. You need immigrants."

Raza says that the travel restrictions announced by the Trump administration confirmed some of her worst fears. "The holder of the highest office in the world is calling out and saying 'stay away," she says. The uncertainty surrounding the nation is already making it harder to recruit foreign researchers, she adds. "Some people don't want to come to the United States. If they can get a position in Europe or Asia, why would they want to come here?"

Similarly, Glover worries that the Brexit vote might make it harder to recruit foreign talent. On a practical level, Brexit might mean that researchers who come to the United Kingdom may no longer be able to apply for EU grants or participate in EU consortia. "If I was an American scientist, I might decide to go to Germany or Spain instead," she says. And then there's the symbolism. The vote has sent a message to researchers worldwide that the United Kingdom might not be a welcoming place, Glover says. "Whether that's reality or not, that's the perception."

Cronin says that he'll be keeping close tabs on any shift in immigration policies under UK Prime Minister Theresa May. "If things change direction, I'll start lobbying," he says. "If it becomes impossible for me to get the right people, I would leave the UK and move the lab to a more open-minded country where excellence is the only requirement." He adds that he's still hopeful that the United Kingdom will continue to be a beacon for top-notch scientists from around the world. "But," he says, "I have my doubts."

\section{Chris Woolston is a freelance writer in} Billings, Montana.

\section{CORRECTION}

The Careers Feature 'Cultivate the muse' (Nature 542, 381-383; 2017) incorrectly described Gaia Bistulfi as a computational biologist. She is, in fact, a molecular biologist.

\section{POSTGRADUATES}

\section{Ireland beckons}

Postgraduates from outside the European Union who have earned doctoral or master's degrees at institutions in Ireland now have up to 24 months to seek employment in the country after graduating. The Irish government doubled the 'stay-back' period from the earlier one-year cut-off. During the two-year period, holders of $\mathrm{PhDs}$ or master's degrees can seek a green-card visa or work permit, look for a job and work for up to 40 hours a week. Ministers announced the policy on 2 February, six days after US President Donald Trump tried to block entry into the United States for citizens of seven Muslimmajority nations. Last October, the Irish government unveiled its 'Irish Educated, Globally Connected' strategy, which aims to increase Ireland's international-student enrolment from 33,118 in 2014/2015 to 44,000 by the end of $2019 / 2020$ and revenue from those students from $€ 1.58$ billion (US $\$ 1.67$ billion) annually to $€ 2.1$ billion. Under the strategy, Ireland is also targeting students from Canada, Mexico, Chile, Argentina, South Korea, Vietnam, Indonesia and Nigeria.

\section{EQUITY}

\section{One step forward}

One in five faculty members at York University in Toronto, Canada, could come from minority communities following an agreement between the institution's faculty association and the university, according to a report by the Canadian Association of University Teachers (CAUT). The university also agreed to recruit at least four Aboriginal academics and acknowledged that staff members who are from lesbian, gay, bisexual, transgender, queer and two-spirit (LGBTQ2S) communities are an 'underrepresented group. The agreement comes after a decade of negotiations between Canadian faculty unions and universities on an equity agenda. Several unions have made gains for women, Aboriginal peoples, the LGBTQ2S community and those with disabilities. In its report, CAUT - which represents 30,000 faculty researchers and other education professionals - said that a government minister has agreed to tackle equity in federal research programmes. Last autumn, CAUT reiterated to the government that fundamental research programmes must be inclusive and reflect the diversity of Canada's research community. 